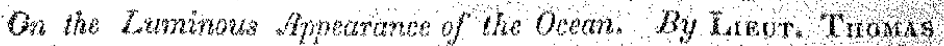

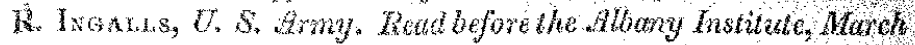
$26,1828$.

Turs beatiful phenomenon, which once bore the poetical title of " phosphorescence of the ocean, "has more recently, fbelieve, rested between two skluting: that it is carsed by animalcula, or by the ovala of fushes. A writer in a recent foreign periodical, inclines to the former opinion-vir. that the tuminos appearance of the ocean is caused by animalcula. As I have becn for some time inclined to the opposite new of this subject, $l$ am induced to submit an account of some observations made a few years since in the humble pursult of science.

In the practice of sea bathing at night, in a southern latitude, I had of course noticed and admired the beautiful "sparkling of the water when agitated or resistedmot the myriads of bodies of whatsoerer sort which emittel these corruscations, were anke invisi ble and impalpable. On one occasion, however, l struck my arm against a small, soft, mass, which immediately emitted a flash of two or thee inches in diumeter. But the mass eluded my attenpts to secure it, as it was invisble the moment iv parted from its accidental contact with my arm. This occurred several times afterwards, and I began to think I perceived a sersation of warmith whenever l struck one of these bothes, thon th aware how hable I was to be deceived by the almost hresistible association of light and heat, in the mind. A very large one ulluately curnined me 1 was not decelved; the sensation being, on this occasion, perfectly flistinct-moteful-and continuing for a minute or wo after the touch.

The masses of murne ovula, left by the tide to heat and hatch on the beach, I had long before observed through the whole process of vivification. Tirst, a transparent mass of jelly-next muked by a white opacue speck, a little distant from the centre -thrd, this spot tringed with a red border, of the colour of arterial blood, next, a kind of irregular pulsation, accompanied by the development of certain white contractle fibres, and the extension of several litge red lines, in molal directions from the focal opaque speck-the ap. pearance of a black speck, ultimately a defined head-mind finally, I have seen the rising tide shake out from the mass, the perfect animal, apparenty in the fall possession of lite; certanly exercising the important function of apprehension of danger.

The identity of this owalum, with the luminous bodies I encountered in the water, appear probable, from thair size, consistency, and their abounding in the same regions. It was soon after ascertained. for on a night when the sea was somewhat agitated, I observed the same corruscations in the waves lreaking on the beach, and succed ed in obtaining several of the illuminting bolles, by the light of their own flashes. They appeared, as I expected, identical.

When exanined by candlelight, to overcome the glare of their 
brilliancy, and at the same time to observe their action more clearly, the power of illumination appeared to realde in a similar focal point, to that described as the place of the first phemomena of vinfifation, and the fashes which conid be procured by irrifatiog the mass with the end of a pencil, diverged from this point, in hies similar in mag. nitude and direction, to the largered ones mentioned in that prow cess. I regret that it did not occur to me, to electrically insulafo one of these bodies, and endeavour to obtain shocks; but I was too much occupied with the guestion above staled, fo avail myself of the means in my hand, of making some interesting experinents on the theory of life.

The existence of those large corruscating bolies in the ocean has been before recorded, and there is, I believe, a paper on this subject, by Dr. Mitehill, published ten or twelve years agro but it is thought some parts of the observations are not on recort, and they are now submitted in the bope of beirg, in some sinall degree, useful or pardoned, if supertituous.

The conclusions I formed on this stbject, were, that in this instance a luminous appearauce in the oceau was produced by marine ovula; and by a rule of philosophizing, all wuch appearances not proved to proced from another sources, aut not inconsistent will this cause, are fairly assignable to the same origin.

Walervlint Arseral.

On the Combination of a Pratical with a Liberal conrse of Dacation,

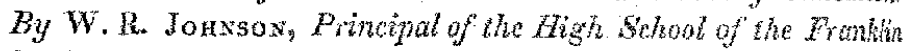
Institute.

\section{No. III}

The course of study, given in the preceding numbor, is not offer ed as a complcte exemplitication of practial and iberat edacation, united. The combiration might, however, be easily extended to the courses pursued athour colleges and universitics. No gool reason can be assigned why the higher branches of mathenatics, logic, ethics, or metaphysics, should not bu pursued simultaneusly with those sciences and arts, which pertain to the active daties of life.

By referring to the course already delineated, the reader will perceive that it consists of four important classes of studies, each of which has generally been confined to a separate school. The first class includes English branches, the second, classicat stullies; the third, nodem langatuges, and the fourth, mathenatics and the prot ticat' sciences.

Whatever be the destination of the student, whether for active life, or for a literary and professional career; whether he shatl finsh his stulies in this institution, or be removed to a university, the im: portance of his English courge will, under every contingency, re: main the same. A correct elocution, a degree of facility both in oral and written composition, knowledge of the great outlines of 